\title{
Determinants of SMEs Growth in the Tamale Metropolis using logistic regression
}

\author{
Eva Atu Alhassan \\ Kwame Nkrumah University of Science and Technology \\ Department of Planning, Kumasi, Ghana \\ E-mail: evaatu@yahoo.com \\ Mabel Akosua Hoedoafia \\ Faculty of Economics and Business Administration \\ Catholic University College of Ghana, Fiapre, Sunyani, Ghana \\ E-mail:mhoedoafia@yahoo.com \\ Elvis Adam Alhassan \\ University for Development Studies \\ Department of Mathematics, Navrongo, Ghana \\ E-mail: aelvis@uds.edu.gh
}

Received: February 26, 2016 Accepted: March 20, 2016

doi:10.5296/ber.v6i1.9107 URL: http://dx.doi.org/10.5296/ber.v6i1.9107

\begin{abstract}
This paper examined the determinants of Small and Medium Enterprises (SMEs) growth in the Tamale Metropolis, Ghana using logistic regression. Growth was measured based on three key performance indicators of gross profits, employment and asset levels. Logistic regressions were estimated to identify the determinants of growth for each of the performance indicators. A survey was conducted on 199 women owned enterprises in the Tamale Metropolis of Ghana that had accessed micro credit from 2010 - 2014. The relationship between the performance indicators and a set of explanatory variables grouped into entrepreneur characteristics, business profile, loan and banking profile and enterprise size were considered. The results showed that entrepreneur characteristics and business profile
\end{abstract}


significantly predicts the growth in gross profits of the SMEs. Specifically the person(s) put in charge of the day-to-day running of the business enterprise had a significant relationship with the growth in gross profit of the enterprise at the $1 \%$ significance level whilst household size of entrepreneur was significant at the 5\% level. However, employment and asset growth were not significantly predicted by the explanatory variables at both the 1 and $5 \%$ levels.

Keywords: SMEs, Growth, Micro Credit, Micro Finance Institutions, Logistic Regression

\section{Introduction}

Women owned Small and Medium Enterprises (SMEs) constitute 75\% of the total SMEs in Ghana and provide enormous contribution to the economic growth and employment creation in the country. In view of this, both researchers and policy makers focus on the need to obtain a better understanding of the factors that influence the performance of these enterprises. Whilst credit has been identified as a major contributor to the growth and success of these enterprises, Sebstad and Walsh (1999) have observed that access to credit was limited. This is due in part to the high cost of borrowing as banks tend to avoid the risk associated with lending to SMEs. Also, most of these enterprises lack the needed collateral to access bank loans, the major traditional source of financing for SMEs. Hence, several Micro Finance Institutions (MFI) have sprung up with the core objective to cater for the credit needs of SMEs to facilitate their growth, many of which have women as their target customers. However, there have been concerns as to whether these MFIs are in business to support these enterprises grow or exploit them and earn higher profits.

There are claims of MFIs charging higher rates of interest coupled with short term repayment period and inadequate amount of credit as required by SMEs. These have the potential to leave a large number of SMEs to either remain small or die out instead of stimulating their growth. On the contrary, proponents of MFIs argue that the SMEs are failing because most operators lack the skills in financial management and planning to prudently invest received credits for the growth of their businesses.

Even though MFIs and commercial banks have been extending credit facility to these SMEs, for an appreciable period, their impact on these enterprises in terms of assets acquired, profits, job creation etc have not been very encouraging. Their effect on SMEs is marginal in terms of growth and competiveness in the business environment. According to Bekele and Zekele (2008), there is stagnation and failure of SMEs in most sub-Saharan African countries. A research carried out in three countries; Kenya, Malawi and Ghana by Buckle (1997) came to the conclusion that there was little evidence to suggest any significant and sustained impact of microcredit services on clients in terms of SME development, increased income flows or level of employment. Burger (1989) also indicated that microcredit tends to stabilize rather than increase income and tends to preserve rather than create jobs.

This study therefore seeks to investigate and analyze the factors that determine the growth of women owned SMEs that access micro credit in Ghana's northern regional capital, Tamale. Growth is mostly deemed as the reliable, most important and easily accessible measure of a firm's performance (Delmar, 1997; Wiklund, 1999). Hence, the determinants of growth were 
examined in terms of growth in three major enterprise performance indicators: gross profit, employment and asset accumulation. Since growth is complex and multidimensional, the determining factors linked to the business owner, business (enterprise) and financial environment (access to finance) were analyzed. The predictors were categorized into four groups as entrepreneur characteristics; business profile; loan and banking profile; and enterprise size. The entrepreneur characteristics included age, household size, marital status, ownership of other businesses and business training accessed. Enterprise size was defined by the number of employees whilst business profile had characteristics such as number of years of operation and who runs the business (manager). The amount of first MFI loan received, number of assets at first MFI loan and number of assets at the time of this study were the factors considered under loan and business profile. Several authors have assessed the effects of microcredit on SMEs performance but not determinants of growth. Also the little research on growth determinants in Africa have been general and not limited to women owned enterprises that form the majority of SMEs. Hence, this paper fills these gaps by assessing the determinants of growth of women owned small and medium enterprises. The paper also adds to the current literature of SMEs especially from the perspective of women entrepreneurs. Additionally, the paper brings to light the growth prospects of microenterprises in the Tamale Metropolis, which is essential for potential investors in the area.

The rest of the paper is organized as follows: section two focuses on the review of relevant literature. The research methodology employed is captured in section three. Section four presents and discusses the results and section five concludes.

\section{Literature review}

\subsection{SME Growth and Development}

The goal of any firm or business is to make profit and grow. A firm is defined as an administrative organization whose legal entity or frame work may expand in time with the collection of both physical resources and intangible resources that may be human in nature (Penrose, 1995). The term growth in this context is that defined by (Penrose, 1995) as an increase in size or other objects that can be quantified or a process of change or improvements. The firm size is the result of firm growth over a period of time and it should be noted that firm growth is a process while firm size is a state (Penrose, 1995). The growth of a firm can be determined by supply of labour, Capital and opportunities for investments that are profitable (Ghoshal, et al., 2002).

SMEs play an important role in the world economy and contribute substantially to income, output and employment. They make a huge contribution to Gross Domestic Product (GDP) and employment. Although precise up-to-date data are difficult to obtain, estimates suggest that more than $95 \%$ of enterprises across the world are SMEs, accounting for approximately $60 \%$ of private sector employment (Ayyagari, 2011). In South Africa, it is estimated that $91 \%$ of the formal business entities are SMEs (Abor and Quartey, 2010) whereas $92 \%$ of companies in Ghana are classified as micro, small and medium enterprises. These enterprises are said to contribute about $70 \%$ of Ghana's GDP and $85 \%$ of employment in the manufacturing industry. Hence impacts on economic growth, income and employment (World 
Bank, 2013).

The contribution of SMEs to the growth of national economies is significant globally. They are important players of national development. SMEs are also important to less developed countries as they make significant contributions to both GDP and employment. A survey of businesses across 99 countries revealed that firms with between 5 and 250 employees accounted for $67 \%$ of the total permanent, full-time employment (Ayyagari, 2011). SMEs were also creating more jobs than large enterprises. The above provide the motivation and relevance of this paper.

\subsection{Indicators of SME Growth}

The success of SMEs is measured by performance indicators which are commonly used to help define and evaluate how successful an organization is, typically in terms of progress made towards its long term organizational objectives (Fitz-Gibbon, 1990). These quantifiable measurements are agreed beforehand and reflect the critical success factors of an organization. Performance measurements must be done in the same terms in which standards have been laid down so that comparisons are easier and meaningful. Performance of SMEs can be measured monetarily with indicators such as profitability analysis, value of assets held and savings made. It can also be measured quantitatively like units of production, units of sales/percentage of market share and quantity of stock held. According to Sebstad et al., (1995), there are different indicators of growth of SMEs.

This paper employed gross profits, accumulation of business assets, and employee growth as indicators of growth for the enterprises studied. According to USAID (2002), the standard measure of growth used in studies of SMEs is the change in the number of workers over a period of time. This variable is comparatively easy for respondents to remember and does not need to be deflated. In addition, Liedholm and Mead (1999) contend that job creation is an important social goal and development objective to support small enterprises and are frequently justified on their supposed employment effects (Voulgaris et al., 2003). Therefore, the predictors of growth studied in this paper are based on growth in profits, employment and assets.

\section{Methodology}

\subsection{Study Area}

The Tamale Metropolis is located in the central part of the Northern Region and has a total estimated land size of $550 \mathrm{~km}$ sq. (MoFEP, 2014). According to the 2010 population and housing census, the Metropolis had in 2010 a total population of 371,351 with males constituting 185,995 and females 185,356 (GSS, 2012). The Northern region, one of the three regions of the northern sector, has a lot of small businesses striving to succeed due to its relatively poor population (Odi \& CEPA report, 2005). The Region is the largest in terms of land area covering 70,384 square kilometres of the Ghanaian landmass. The informal and formal private sector absorbs about $83.4 \%$ and $11.5 \%$ respectively of the total population of the region with the formal sector employing only $4.3 \%$ (Government of Ghana Portal). This informal sector is highly characterized by entrepreneurs with no formal education: about 
69.3\% as revealed in Alhassan, Hoedoafia \& Alhassan (2016). A number of businesses in this area are also unregistered, only $3 \%$ of women owned businesses were found to be registered according to a survey of 199 businesses (Alhassan, Hoedoafia \& Alhassan, 2016).

\subsection{Sampling and Research Design}

A list of women entrepreneurs in the study area that have benefited from credit facilities from 2010-2014 was generated from the sampled microfinance institutions through a pilot study. This amounted to a total of 20,394 women entrepreneurs. After which a sampling formula by Yamane (1967) was used to determine the sample size.

$$
\mathrm{n}=\mathrm{N} / 1+\mathrm{N}\left(\infty^{2}\right)
$$

Where $\mathrm{n}=$ Sample Size; $\mathrm{N}=$ Population or Sampling frame; $\infty=$ Margin of Error

$$
\mathrm{N}=20,394 / 1+20,394(0.07)^{2}=202
$$

Although the sample size was 202 women entrepreneurs, 199 women readily availed themselves to be interviewed. This however, does not make the results biased as there is no significant change in the margin of error (i.e $\infty$ increased from 0.07 to 0.071 ).

Table 1. Sample Size Distribution by Microfinance Institutions.

\begin{tabular}{|l|l|l|l|}
\hline Microfinance Institutions & Area of Operation & $\begin{array}{l}\text { Total Number of Women Beneficiaries } \\
\text { (entrepreneurs) }\end{array}$ & Sample \\
\hline 1. Snapi Aba & $\begin{array}{l}\text { Ata Asibi-Hospital } \\
\text { road }\end{array}$ & 3,927 & 24 \\
\hline $\begin{array}{l}\text { 2.Baobab Microfinance Co. } \\
\text { Ltd }\end{array}$ & Lamashegu & 6,000 & 54 \\
\hline $\begin{array}{l}\text { 3. Utrak Savings and } \\
\text { Loans }\end{array}$ & $\begin{array}{l}\text { Gumbihni/Water } \\
\text { works }\end{array}$ & 209 & 43 \\
\hline $\begin{array}{l}\text { 4.Innovative Microfinance } \\
\text { Ltd }\end{array}$ & $\begin{array}{l}\text { Gumbihni/Water } \\
\text { works }\end{array}$ & 10,120 & 64 \\
\hline $\begin{array}{l}\text { 5.Global Trust Microfinance } \\
\text { Ltd }\end{array}$ & Aboaboo & 138 & 14 \\
\hline Total & & 20,394 & 199 \\
\hline
\end{tabular}

Source: Authors construct with data from the Microfinance institutions.

Purposive sampling technique was then used to select the women entrepreneurs from the sampled MFIs who have benefited from microcredit. This technique was very useful since it helped to reach targeted samples quickly and also helped to get easily the opinions of the targeted population. Stratified sampling was further used to categorize the women into 5 strata based on their economic activities as Petty trading; Agro-Processing; Bakery; Dressmaking; and Hairdressing.

Quantitative data was collected from the owners or managers of all the sampled SMEs using a semi-structured questionnaire. The data gathered was analyzed with two main statistical software programmes, SPSS and STATA, The purpose was to combine the advantages of the 
two software programmes. Data entry, descriptive data analysis were done in SPSS v.20. The data was then coded and imported into STATA v.13 which was used for the binary logistic regression estimation.

\subsection{Model Specification}

The paper employed a binary logistic regression model since the dependent variable was dichotomous (only two outcomes/categories).

\subsubsection{Dependent Variables}

In binary logistic regression, the dependent variable is dichotomous thus, it only contains data coded as 1 (success) or 0 (failure). In this paper, success and failure were operationally defined as Yes and No respectively. Hence each of the dependent variables was given dichotomous definitions as:

- Gross Profit Growth: (Positive Gross Profit Growth =1 (Yes), Gross Profit Decline or no change in Growth $=0$ (No)

- Employee Growth: (Positive Employee Growth =1 (Yes), Decline or no change in Employee Growth $=0$ (No)

- Asset Growth: (Positive Asset Growth =1 (Yes), Decline or no change in Asset Growth $=0(\mathrm{No})$

The variables employed in this paper are described in table 2 below.

Table 2. Description of Variables

\begin{tabular}{|l|l|}
\hline Variables & Description \\
\hline Gross profit growth & Change in profit over time \\
\hline Employee growth & Increase in the number of workers over time \\
\hline Asset growth & Acquisition of new assets after accessing microcredit \\
\hline Enterprise size & Number of employees \\
\hline Entrepreneur characteristics & Age, household size, marital status of owner \\
\hline Business profile & Number of years of operation and who runs the business \\
\hline Loan profile & Amount of loan received \\
\hline
\end{tabular}

In logistic regression, the goal is to predict the chances of dependent variable occurring given values of independent variable(s). To predict the probability of $\mathrm{Y}$, the equation below was transformed using logit function:

$$
Y=\beta_{0}+\beta_{1} X_{1}+\beta_{2} X_{2}+\beta_{3} X_{3}+\ldots \ldots \ldots \beta_{k} X_{k}
$$

Logit transformation of the probability of event can be expressed as:

$$
\operatorname{Logit}(p)=\ln \left(\frac{p}{1-p}\right)=\beta_{0}+\beta_{1} X_{1}+\beta_{2} X_{2}+\beta_{3} X_{3}+\ldots \ldots \ldots \ldots \beta_{k} X_{k}
$$

Where $\beta_{0}$ is the model constant, $\quad \beta_{1}, \beta_{2}, \beta_{3} \ldots \beta_{k}$ are the parameters of the independent 
variables and the set of independent variables $\left(\mathrm{X}_{1}, \mathrm{X}_{2}, \mathrm{X}_{3}, \ldots, \mathrm{X}_{\mathrm{k}}\right)$. The range of logistic function is between 0 and 1 , which makes it suitable for use as probability model.

Logit function, logit (p) is defined as:

$$
\operatorname{logit}(p)=\ln \left(\frac{p}{1-p}\right)
$$

Where $\mathrm{p}$ is the probability that an event will occur and it ranges from 0 to 1 . By taking the exponential of both sides of the above logit (p) equation, the equation was rewritten as:

$$
O d d s=\left(\frac{p}{1-p}\right)=\mathrm{e}^{\beta_{0}} \times \mathrm{e}^{\beta_{1} X 1}{ }_{\mathrm{x}} \mathrm{e}^{\beta_{2} X_{2}} \times \mathrm{e}^{\beta_{3} X_{3}} \times \ldots \ldots \ldots . . . \mathrm{e}^{\beta_{k} X k}
$$

\section{Results and Discussions}

\subsection{Logistic Regression Results on the Predictors of Gross Profit Growth}

The results (see table 3) showed that among the set of variables affecting gross profit growth, the person(s) who is put in charge of the day-to-day running of the business enterprise had a significant relationship with the growth in gross profit of the enterprise. Specifically, the model revealed that when the business is run on a day-to-day basis by both the entrepreneur (self) and family members, then odds of experiencing growth in gross profits is reduced by 93.7\% compared to when the business is run on a day-to-day basis by entrepreneur (self). These results were significant $(b=-2.76442, z=-2.849$, odds ratio $=0.0630, p=0.004)$. Similarly, the model revealed that when the business is run on a day-to-day basis by both the entrepreneur (self) and non-family members, then odds of experiencing growth in gross profits is reduced further by $97.4 \%$ compared to when the business is run on a day-to-day basis by entrepreneur (self). These results were also significant $(\boldsymbol{b}=\mathbf{- 3 . 6 3 7 4 1}, \boldsymbol{z}=\mathbf{- 2 . 1 9 2}$, odds ratio $=0.0263, p=0.028$ ). These results indicate that the responsibility of the day-to-day running of the business enterprise should be taken up by the entrepreneur (self) in order to achieve growth in gross profits since delegating this responsibility to family or non-family members tends to reduce the odds of achieving growth in gross profits. The results are in line with (Feeser and Willard, 1990) who postulate that enterprises with several managers tend to slow down decision making process which has the potential to limit growth. These findings contrast Vesper (1990), who posits that firms headed by a team of managers grow to a large extent than single manager enterprises because of greater variety and balance of skills and risk. Other studies with differing results like Vesper (1990) are (Dunkelberg et al., 1987; Woo et al., 1989; Feeser and Willard, 1990; Siegel et al., 1993; Weinzimmer, 1993) that maintain that growth is positively related to the number of enterprise managers.

On the other hand, age, marital status, household size and number of assets at first MFI loan have odds ratio greater than 1 , implying that a unit change in the logit coefficient increases the logit (gross profit) by the value of the logit coefficient (b). For instance, an increase in the age of the entrepreneur by one year will result in an increase in the gross profit by 0.06849 
(GHS 6.849). Likewise an increase in the household size by one member will bring about a 0.33829 (GHS 33.829) increase in gross profits. The rest of the predictor variables have odds ratio less than 1 , implying that a unit change in (b) reduces the logit by the value of the (b). although not all are significant at the $1 \%$ or $5 \%$ level of significance. For example, an increase in the number of the management of the enterprise by one personnel (either family member or non-family member) will lead to a decline in gross profits by 2.76442 (GHS 276.442) and 3.63741 (GHS 363.741) respectively.

Table 3. Logistic regression results on the predictors of gross profit growth

\begin{tabular}{|c|c|c|c|c|c|c|c|}
\hline Parameters & $\mathrm{b}$ & $\mathrm{z}$ & $\mathrm{P}>|\mathrm{z}|$ & $\begin{array}{c}\text { Odds ratio } \\
\left(\mathrm{e}^{\wedge} \mathrm{b}\right)\end{array}$ & $\%$ & $\%$ StdX & SDofX \\
\hline Age & 0.06849 & 1.120 & 0.263 & 1.0709 & 7.1 & 63.7 & 7.1929 \\
\hline Marital status (1=Monogamy) & & & & & & & \\
\hline 2.Polygamy & 0.99994 & 1.083 & 0.279 & 2.7181 & 171.8 & 61.7 & 0.4807 \\
\hline 3.Not married & 0.05356 & 0.053 & 0.958 & 1.0550 & 5.5 & 1.8 & 0.3241 \\
\hline Household size & 0.33829 & 1.717 & 0.086 & 1.4025 & 40.3 & 246.8 & 3.6758 \\
\hline $\begin{array}{c}\text { Accessed Business Training } \\
\text { (Yes=1) }\end{array}$ & -0.22377 & -0.156 & 0.876 & 0.7995 & -20.0 & -6.4 & 0.2937 \\
\hline $\begin{array}{c}\text { Ownership of other business } \\
\text { (Yes=1) }\end{array}$ & -0.17721 & -0.186 & 0.852 & 0.8376 & -16.2 & -6.6 & 0.3835 \\
\hline $\begin{array}{c}\text { Number of Years of business } \\
\text { operation }\end{array}$ & -0.03777 & -0.614 & 0.539 & 0.9629 & -3.7 & -23.9 & 7.2216 \\
\hline $\begin{array}{c}\text { Who runs the business (Self }=1) \\
\text { 2.Self \& family members }\end{array}$ & -2.76442 & -2.849 & $0.004 * * *$ & 0.0630 & -93.7 & -74.0 & 0.4874 \\
\hline $\begin{array}{c}\text { 3.Self \& other non-family } \\
\text { members }\end{array}$ & -3.63741 & -2.192 & $0.028 * *$ & 0.0263 & -97.4 & -67.6 & 0.3095 \\
\hline $\begin{array}{c}\text { First MFI loan received } \\
\text { Number employed at First MFI } \\
\text { loan }\end{array}$ & -0.00077 & -1.105 & 0.269 & 0.9992 & -0.1 & -26.7 & 405.035 \\
\hline $\begin{array}{c}\text { Number of people employed at } \\
\text { time of study }\end{array}$ & -1.00425 & -0.976 & 0.329 & 0.3663 & -63.4 & -49.6 & 0.6815 \\
\hline $\begin{array}{c}\text { Number of Assets at First MFI } \\
\text { loan }\end{array}$ & -0.28606 & -0.700 & 0.484 & 0.7512 & -24.9 & -26.4 & 1.0734 \\
\hline Number of Assets at time of study & -0.05274 & -0.398 & 0.691 & 0.9486 & -5.1 & -20.0 & 4.2214 \\
\hline
\end{tabular}

$* * *$ Significant at $1 \%, * *$ Significant at $5 \%$, Number of observations $=126$,

LR chi2 $(11)=24.52$, Prob $>$ chi $2=0.0107$, Log likelihood $=-25.0658$, Pseudo $R 2=0.3285$

\subsection{Logistic Regression Results on the Predictors of Employee Growth}

Access to business training, ownership of other businesses and number of assets at the time of study have odds ratio greater than 1, implying that a unit change in the logit coefficient increases the logit (employee growth) by the value of the logit coefficient (b). For example, increasing the management personnel by one non-family member will result in employee 


\section{Al Macrothink}

Business and Economic Research ISSN 2162-4860 2016, Vol. 6, No. 1

growth by two persons. The rest of the predictor variables have odds ratio less than 1 , implying that a unit change in (b) reduces the logit by the value of the (b), although none of the predictor variables are significant at the $1 \%$ or $5 \%$ level of significance. Janssen (2003) concludes that the mere presence of a team of managers does not predict employment growth but rather their expertise. He also found that age does not determine employment growth just like in this study.

Table 4. Logistic regression results on the predictors of employee growth

\begin{tabular}{|c|l|l|l|l|l|l|l|}
\hline Parameters & $\mathrm{b}$ & $\mathrm{z}$ & $\mathrm{P}>|\mathrm{z}|$ & \multicolumn{1}{|c|}{ Odds ratio $\left(\mathrm{e}^{\wedge} \mathrm{b}\right)$} & $\%$ & $\%$ StdX & SDofX \\
\hline Age & -.01394 & -0.185 & 0.853 & 0.9862 & -1.4 & -9.4 & 7.0955 \\
\hline Household size & -.01594 & -0.121 & 0.904 & 0.9842 & -1.6 & -6.0 & 3.8678 \\
\hline Accessed Business Training (Yes $=1)$ & 0.24126 & 0.199 & 0.842 & 1.2729 & 27.3 & 9.8 & 0.3878 \\
\hline Ownership of other business (Yes $=1)$ & 0.26085 & 0.251 & 0.802 & 1.2980 & 29.8 & 10.6 & 0.3878 \\
\hline Number of Years of business operation & -0.01247 & -0.183 & 0.855 & 0.9876 & -1.2 & -8.9 & 7.4736 \\
\hline Who runs the business (Self=1) & & & & & & & \\
\hline 2.Self \& family members & -0.58012 & -0.514 & 0.607 & 0.5598 & -44.0 & -24.7 & 0.4894 \\
\hline 3.Self \& other non-family members & 2.18188 & 1.648 & 0.099 & 8.8629 & 786.3 & 85.6 & 0.2834 \\
\hline First MFI loan received & -0.00291 & -1.228 & 0.219 & 0.9971 & -0.3 & -66.6 & 377.46 \\
\hline Number of Assets at First MFI loan & -0.23414 & -0.613 & 0.540 & 0.7913 & -20.9 & -67.5 & 4.8011 \\
\hline Number of Assets at time of study & 0.41093 & 0.968 & 0.333 & 1.5082 & 50.8 & 510.8 & 4.4036 \\
\hline
\end{tabular}

$* * *$ Significant at $1 \%, * *$ Significant at $5 \%$, Number of observations $=126$,

LR $\operatorname{chi} 2(11)=24.52$, Prob $>$ chi $2=0.0107$, Log likelihood $=-25.0658$, Pseudo $R 2=0.3285$

\subsection{Logistic Regression Results on the Predictors of Asset Growth}

Age, ownership of other business and number of employees at the time of the study have odds ratio greater than 1, implying that a unit change in the logit coefficient increases the logit by the value of the logit coefficient (b). Hence, an additional one employee will bring about an increase in asset growth by $0.02166(2.166 \%)$. The first MFI loan has an odds ratio $=1$, meaning that a unit change in (b) has no effect on the logit (Asset growth) whilst the rest of the predictor variables have odds ratio less than 1, implying that a unit change in (b) reduces the logit by the value of (b), although none of the predictor variables are significant at the $1 \%$ or $5 \%$ level of significance. McCarthy et al. (1993) corroborates this results that found that there was no link between number of enterprise managers and asset growth. 
Table 5. Logistic regression results on the predictors of asset growth

\begin{tabular}{|c|l|l|l|l|l|l|}
\hline Parameters Age & $\mathrm{b}$ & $\mathrm{z}$ & $\mathrm{P}>|\mathrm{z}|$ & Odds ratio $\left(\mathrm{e}^{\wedge} \mathrm{b}\right)$ & $\%$ StdX & SDofX \\
\hline Marital status (Not married $=1)$ & -0.28716 & -0.434 & 0.664 & 0.7504 & 0.9174 & 0.3001 \\
\hline Household size & 0.05591 & 1.113 & 0.266 & 1.0575 & 1.2483 & 3.9663 \\
\hline Accessed Business Training (Yes=1) & -0.73219 & -1.482 & 0.138 & 0.4809 & 0.7611 & 0.3729 \\
\hline Ownership of other business (Yes=1) & 0.13464 & 0.268 & 0.789 & 1.1441 & 1.0531 & 0.3845 \\
\hline Number of Years of business operation & -0.02002 & -0.728 & 0.467 & 0.9802 & 0.8575 & 7.6789 \\
\hline Who runs the business & -0.71795 & -1.650 & 0.099 & 0.4877 & 0.6992 & 0.4985 \\
(Self=1) & & & & & & \\
\hline First MFI loan received & 0.00099 & 1.681 & 0.093 & 1.0010 & 1.4151 & 351.16 \\
\hline Number of employees at First MFI loan & -0.07800 & -0.240 & 0.810 & 0.9250 & 0.9523 & 0.6261 \\
\hline Number of employees at time of study & 0.02166 & 0.099 & 0.921 & 1.0219 & 1.0200 & 0.9143 \\
\hline
\end{tabular}

$* * *$ Significant at $1 \%, * *$ Significant at $5 \%$, Number of observations $=151$,

LR chi2 $(10)=16.03$, Prob $>$ chi2 $=0.0988$, Log likelihood $=-83.098$, Pseudo R2 $=0.0880$

Unlike gross profit growth, the results of tables 4 and 5 however showed that none of the set of explanatory variables considered (entrepreneur characteristics, business profile, loan and banking profile and enterprise size) were significant determinants of employee growth status or asset levels.

\section{Conclusion}

The determinants of Small and Medium Enterprises (SMEs) growth in the Tamale Metropolis in terms of growth in gross profits, employment and asset levels using logistic regressions were estimated. The Metropolis is highly dominated by the private sector especially the informal private sector. The businesses that are operated in the area are mostly small and medium enterprises with most entrepreneurs having no formal education. Predictor variables relating to those of the owner and enterprise as well as the financial environment were considered. The results showed that among the set of variables pertaining to gross profit growth, the person(s) who run the business enterprise had a significant relationship with the growth in gross profit of the enterprise. The logit model revealed that the odds of experiencing growth in gross profits is reduced by $93.7 \%$ when the business is run by both the entrepreneur (self) and other family members. Also, it was found that when the business is run on a day-to-day basis by both the entrepreneur (self) and non-family members, the odds of experiencing growth in gross profits is reduced further by $97.4 \%$ compared to when the business is run on a day-to-day basis by entrepreneur (self). The results however showed that none of the set of explanatory variables considered (entrepreneur characteristics, business profile, loan and banking profile and enterprise size) was a significant determinant of employee or asset growth. 


\section{References}

Abor, J., \& Quartey, P. (2010). Issues in SME Development in Ghana and South Africa. International Research Journal of Finance and Economics, 39, 218-228

Alhassan, A. E., Hoedoafia, A. M., \& Alhassan, A. E. (2016). Entrepreneurial Characteristics and Business Profile of Women owned Small and Medium Enterprises (SMEs): A case study of the Tamale Metropolitan area. Upcoming in: Business Management and Strategy.

Atandi, F. G., \& Wabwoba T. B. (2013). Effect of Credit on Micro and small Enterprises Performance in Kitale Town. International Journal of Academic Research in Business and Social Sciences, 3(9), 570-583. http://dx.doi.org/10.6007/IJARBSS/v3-i9/244

Ayyagari, M. (2011). Small and medium enterprises across the globe. Small Business Economics, 29(4), 415-434. http://dx.doi.org/10.1007/s11187-006-9002-5

Bekele, E., \& Zekele,E. (2008). Factors that affect the long-term survival of micro, small and medium enterprises in Ethiopia. South African Journal of Economics, 76(3), 1-33. http://dx.doi.org/10.1111/j.1813-6982.2008.00207.x

Buckley, G. (1997). Microfinance in Africa: Is it either the Problem or the Solution? World Development report, 25(7), 1081-1091. http://dx.doi.org/10.1016/S0305-750X(97)00022-3

Burger, M. (1989). Giving Women Credit: The Strengths and Limitations of Credit as a tool for Alleviating Poverty. World Development, 17(7), 1017-1032. http://dx.doi.org/10.1016/0305-750X(89)90165-4

Delmar, F. (1997). Measuring growth: methodological considerations and empirical results, in Donckels, R. and Miettinen, A. (ed.) (1997), Entrepreneurship and SME research: on its way to the next millennium, Aldershot, Ashgate.

Dunkelberg, W. G., Cooper, A. C., Woo, C., \& Dennis, W. J. (1987). New firm growth and performance, in Churchill, N.C., Hornaday, J.A., Kirchoff, B.A., Krasner, C.J. and Vesper, K.H. (ed.), Frontiers of entrepreneurship research, Boston (Mass.), Babson College

Fitz-Gibbon, C. T. (1990). Analysing Examination Results. In Fitz-Gibbon, C. T. (editor), "BERA DIALOGUES, No. 2, Performance Indicators", Clevedon.

Feeser, H. R., \& Willard, G. E. (1990). Founding strategy and performance: a comparison of high and low growth tech firms. Strategic Management Journal, 11, 87-98. http://dx.doi.org/10.1002/smj.4250110202

Ghoshal, S., Hahn, M., \& Moran, P. (2002). Management competence, firm growth and economic progress In C. Pitelis. (Ed.), The growth of the firm: the legacy of Edith Penrose: 279-308. Oxford: Oxford University Press. http://dx.doi.org/10.1093/cpe/18.1.121

GSS (2012). 2010 Population and Housing Census. Summary report of final results. [Online] Available:http://www.statsghana.gov.gh/docfiles/2010phc/Census2010_Summary_report_of_ final_results.pdf (July 7, 2014) 
Janssen, F. (2003). Determinants of SMEs' Employment Growth Relating to the Characteristics of the Manager. IAG - LSM Working Papers - 03/93, 1 - 29

Liedholm, C., \& Mead, C. D. (1999). Small Enterprises and Economic Development: The Dynamics of micro and small enterprises, Rutledge Studies in Development Economics, New York. http://samples.sainsburysebooks.co.uk/9781135118082_sample_504631.pdf

McCarthy, A. M., Schoorman, D. F., Cooper, A. C. (1993). Reinvestment decisions by entrepreneurs: rational decision-making or escalation of commitment. Journal of Business Venturing, 8, 9-24. http://dx.doi.org/10.1016/0883-9026(93)90008-S

MoFEP (2014). The Composite Budget of The Tamale Metropolitan Assembly for the 2014 Fiscal Year. [Online] Available: www.mofep.gov.gh (September 9, 2014)

Penrose, E. (1995). The theory of the growth of the firm. Oxford: Oxford University Press. http://dx.doi.org/10.1093/0198289774.001.0001

Sebstad, J., \& Walsh, M. (1999). Micro enterprise credit and its effects in Kenya. An exploratory study. Final report Ernst and young, Nairobi.

Sebstad, J., Neill, C., Barnes, C., \& Chen, G. (1995). Assessing the Impacts of Microenterprise: A Framework for Analysis. [Online] Available: http://pdf.usaid.gov/pdf_docs/PNABS523.pdf

Stewart, M., \& Hodgjinson, P. E. (1991). Coping with Catastrophe. A handbook of Disaster Management. London, Routledge. [Online] Available: https://books.google.com.gh/books 4. (September 20, 2014)

USAID (2001). USAID and Microenterprise Development. Financial Services Funding by Region (1996-2001). [Online] Available: http://www.usaidmicro.org/About/Funding_FS.asp (August 5, 2014 )

USAID (2002). Mainstreaming Trade: A Poverty Reduction Strategy for Mozambique, Nathan Associates. [Online] Available: http://www.nathaninc.com/sites/default/files/Mainstreaming-Trade-Poverty-Reduction-Strate gy-for-Mozambique.pdf (September 8, 2014)

Vesper, K. H. (1990). New venture strategies (Revised edition), Englewood Cliffs (NJ), Prentice Hall

Voulgaris, F., Asteriou, D., \& Agiomirgianaki, G. (2003). The Determinants of small firm growth in the Greek manufacturing sector. Journal of Economic Integration, 18(4), 817-836. http://dx.doi.org/10.11130/jei.2003.18.4.817

Weinzimmer, L. G., Nystrom, P. C., \& Freeman, S. J. (1998). Measuring organizational growth: issues, consequences and guidelines. Journal of Management Studies, 24(2), 235-262. http://dx.doi.org/10.1016/S0149-2063(99)80061-0

Wiklund, J. (1999). The sustainability of the entrepreneurial orientation-performance relationship. Entrepreneurship Theory and Practice, 24(1), 37-48 


\section{Macrothink}

Business and Economic Research ISSN 2162-4860 2016, Vol. 6, No. 1

Woo, C. Y, Cooper, A. C., Dunkelberg, W. C., Daellenbach, U., \& Dennis, W. J. (1989). Determinants of growth for small and large entrepreneurial start-ups. Babson entrepreneurship conference

World Bank (2013). The Little Data Book on Gender 2013. Washington DC: The World Bank. [Online] Available: http://data.worldbank.org/sites/default/files/the-little-data-books-on-gender-2013.pdf 4. (October 10, 2014)

Yamane, T. (1967). Statistics: An Introductory Analysis (2nd ed.). New York: Harper and Row.

\section{Copyright Disclaimer}

Copyright for this article is retained by the author(s), with first publication rights granted to the journal.

This is an open-access article distributed under the terms and conditions of the Creative Commons Attribution license (http://creativecommons.org/licenses/by/3.0/). 